\title{
Determining Factors of Cloud Computing Adoption: A Study of Indonesian Local Government Employees
}

\author{
Nur Restu Amalia Salam ${ }^{1}$ and Syaiful $\mathrm{Ali}^{2 *}$
}

\begin{abstract}
:
Research aims: This study aims to identify the factors that influence the Indonesian local government employees to adopt cloud computing.

Design/Methodology/Approach: A Unified Theory of Acceptance and Use of Technology (UTAUT) theory were employed to identify these factors. Research data were obtained using an online survey of employees, working in local governments in Indonesia. This study obtained 123 responses, which were then processed utilizing the structural equation modeling approach.

Research findings: The results showed that Performance Expectations, Business Expectations, and Perception of Availability had a positive effect on the intention of local government employees to use cloud computing.

Theoretical contribution/ Originality: This study expanded the UTAUT model by including security factors. Thus, creating a new cloud computing adoption model contributed to a theoretical finding in the context of government cloud computing adoption.

Practitioner/Policy implication: The results of this study make practical contributions to cloud computing service providers in order to understand what factors drive the adoption of cloud computing by local government employees. In addition, the study also helps the top management in local government organizations to develop adoption strategies by understanding the influential determinants of cloud computing adoption on their employees.

Research limitation/Implication: The context of this study is restricted to Indonesian local government employees. The local government employees have their characteristics, and it is different from other government employees in the central government.
\end{abstract}

${ }_{1}$ Masters in Science, Universitas Gadjah Mada, Daerah Istimewa Yogyakarta, Indonesia.

\footnotetext{
${ }^{2}$ Department of Accounting, Universitas Gadjah Mada, Daerah Istimewa Yogyakarta, Indonesia.
}

\section{*CORRESPONDENCE:}

s.ali@ugm.ac.id

THIS ARTICLE IS AVAILABLE IN:

http://journal.umy.ac.id/index.php/ai

DOI: 10.18196/jai.2102151

\section{CITATION:}

Salam, N. R. A., \& Ali, S. (2020). Determining Factors of Cloud Computing Adoption: A Study of Indonesian Local Government Employees. Journal of Accounting and Investment, 21(2), 312-333.

\section{ARTICLE HISTORY}

\section{Received:}

1 February 2020

Reviewed:

9 February 2020

Revised:

14 April 2020

Accepted:

5 May 2020
Keywords: Cloud Computing; Employee; Local Government; UTAUT

\section{Introduction}

The development of Information, Communication, and Technology (ICT) has given a significant impact on services in public sector organizations (i.e., E-Government). One of the information technology innovations that can support the use of e-Government to improve government service functions is through the use of Cloud Computing. National Institute of Standards and Technology (NIST, 2013) explained that the use of cloud computing in an organization facilitates the dissemination and access to broader information. Cloud computing is a combination of computer and internet usage that can build a consolidated data center with many government agencies. Therefore, if applied in government, it can support 
the implementation of e-Government and realize the principles of good governance, such as transparency, effectiveness, and efficiency (Al-Rashedi, 2014; Mohammed, Ibrahim, \& Ithnin, 2016). Several government organizations in developed countries have moved to adopt cloud computing. The United States of America, the United Kingdom, and Japan are examples where cloud computing has played a significant role in the governments' transformation, especially in IT strategy and operations (Sallehudin, Razak, \& Ismail, 2015). Developing countries have also started implementing cloud computing services; for example, China implemented cloud computing services at a local level in cities (example: Dongying and Wuxi). The Malaysian Government has identified cloud computing as a primary focus area and had earmarked cloud computing as the leading strategic technology. The Taiwanese Government announced its Cloud Computing Industry Development Program and plans to spend \$744 million over the next five years to establish cloud computing technology and services. Thailand's Government Information Technology Service (GITS) is putting together a private cloud infrastructure for Government agencies. The Vietnamese Government has collaborated with IBM and educational universities to promote greater adoption of cloud-based services by public and private sectors (Chandrasekaran \& Kapoor, 2011).

Unlike other developing countries, the development of cloud computing in Indonesia is still at a low level. It is shown in the 2018 Global Cloud Computing Scorecard released by BSA The Software Alliance (2018). The scorecard focuses on the policy areas that matter most to cloud computing. It provides seven measured factors, consisting of data privacy, security, cybercrime, intellectual property rights, standards, and international harmonization, promoting free trade, and IT Readiness, Broadband Deployment. The scorecard showed that Indonesia was ranked 23rd out of 24 leading IT economies. The rank was lower compared to its ranking of 20th in 2016, which gives a sign that the legal and regulatory environment for cloud computing in Indonesia is deteriorating. In addition, Bourne (2018) also explained that Indonesia could be seen as one of the weaker countries in the Asia Pacific region for cloud readiness. Several reasons arise, such as the lack of competency for human resources in ICT, lack of integration, an inefficient investment of infrastructure in regions (Ahmad \& Hasibuan, 2012), and the low availability of high-speed internet (Chandrasekaran \& Kapoor, 2011). Therefore, to succeed in implementing e-government based cloud in Indonesia, an investigation on the acceptance of cloud computing should be examined in order to prevent IT failures in government.

Although several studies have discussed the process and results of implementing cloud computing in the government, there is a lack of empirical studies focusing on cloud computing domain and its application adoption in the context of government especially at federal, state, and local government levels (Sallehudin et al., 2015). It is a crucial thing to examine because the adoption stage of cloud computing determines the sustainability and successful implementation of information technology in government. On the other hand, Hartono (2017) explains that identifying the local government employees' preparedness to adopt cloud computing should be performed as one of the preventive acts against IT failures called the paradox of IT in organizations. To address the research gap, this study explored behavior factors that determine the adoption of 
cloud computing in the local government in Indonesia. It is because Indonesia is one of the developing countries, which has 542 autonomous regions, consisting of 34 Provinces, 416 Districts, and 98 Cities (Ministry of Home Affairs of the Republic of Indonesia, 2014). These regions are widespread in Indonesia so that to consolidate regional information from one region to another, and it could deploy cloud-based technology. Nonetheless, the adoption rate of cloud computing in Indonesia is low.

The conceptual model used in this study was based on a Unified Theory of Acceptance and Use of Technology (UTUAT) framework by Venkatesh, Morris, Davis, and Davis (2003). UTAUT identifies four constructs that are direct determinants of intention or behavioral usage (Oliveira, Faria, Thomas, \& Popovič, 2014). According to Venkatesh et al. (2003), these factors are Performance Expectancy, Effort Expectancy, Social Influence, and Facilitating Conditions. Besides, security factors that have the potential to influence the acceptance of cloud computing across most of the world were included (Alassafi, Alharthi, Walters, \& Wills, 2017). The security framework refers to Hartono, Holsapple, Kim, Na, and Simpson (2014), which consists of Perceived Confidentiality, Perceived Integrity, and Perceived Availability. These factors were included as they could explain information technology security risks (Silic \& Back, 2015).

The results of this study indicated that behavioral intentions directly influenced cloud computing adoption (i.e., actual use). Performance Expectancy, Effort Expectancy, and Perceived Availability affected behavioral intention (intention to use). This study contributes to the theoretical and practical knowledge of cloud computing in the context of local government employees. First, from a theoretical perspective, this study expanded the UTAUT model by including security factors. Thus, creating a new cloud computing adoption model contributed to a theoretical finding in the context of government cloud computing adoption. This study identified four influential determinants (i.e., Performance Expectancy, Effort Expectancy, intention to use, and Perceived Availability) of cloud computing adoption by the local government. Second, this study provided practical contributions to cloud computing service providers and top management in the local government. The results of this study make practical contributions to cloud computing service providers in order to understand what factors drive the adoption of cloud computing by local government employees. In addition, the study also helps the top management in local government organizations to develop adoption strategies by understanding the influential determinants of cloud computing adoption on their employees.

\section{Literature Review and Hypotheses Development}

\section{Cloud Computing}

Many developed countries' public sector has adopted cloud computing technology. It has led to improvements in government function in terms of its service to citizens and institutions, and its cooperation with other government organization (Al-Ruithe, Benkhelifa, \& Hameed, 2017). The nature of cloud computing, such as ease of sharing, 
consolidating, and connecting with one centralized data, can offer many advantages to the government, such as improving current IT deployment (Jones, 2015) and cost savings through enhanced systems efficiency (Microsoft, 2016). According to Zwattendorfer and Tauber (2013), three forms of cloud computing services can be used by government agencies in their operational activities. First, Software-as-a-service, one of the services that do not oblige the users to set and control the application service process, such as Salesforce.com, Gmail, and Microsoft Online. Second, Platform-as-aservice, a service distribution by providing a platform to distribute applications that are made into a more extensive cloud infrastructure for the users, for instance, Google Apps and Salesforce. Third, Infrastructure-as-a-service, a service distribution by renting technology information structures to the users who are interested in building a cloud service. They do not need to set and control a cloud infrastructure but control it through operation, storage, and application systems, such as Amazon EC2 and Rackspace Cloud.

\section{UTAUT}

The limitations of the previous models in explaining IT acceptance in organizations lead to the development of the Unified Theory of Acceptance and Use of Technology model (UTAUT) (Venkatesh et al., 2003). The model comprises of eight prominent IT model, which includes TAM (Technology Acceptance Model), TRA (Theory of Reasoned Action), MM (Motivational Model), MPCU (Model of PC Utilization), SCT (Social Cognitive Theory), IDT (Innovation Diffusion Theory), TPB (Theory of Planned Behavior), and CTAM-TPB (Combined TAM and TPB) (Ooi, Lee, Tan, Hew, \& Hew, 2018). According to Oliveira et al. (2014), UTAUT suggests three antecedents to the intention to adopt an IS (Information System), namely Performance Expectancy, Effort Expectancy, and Social Influence. The behavioral intention and facilitating conditions together influence the actual use of the information system. The original UTAUT is shown to account for over $70 \%$ of the variance in user's INT to use a technology (Udo, Bagchi, \& Maity, 2016). Therefore, in this study, UTAUT was used to explore the local government employees' intention to use cloud computing.

UTAUT has drawn the attention of researchers and has been used in different research settings to study behavior intention and technology adoption (Oliveira et al., 2014). In the context of government, the previous study, such as Weerakkody, El-Haddadeh, AlSobhi, Shareef, and Dwivedi (2013), suggested that performance expectancy, effort expectancy, and facilitating conditions had an essential role in explaining the adoption behavior of e-government services offered through intermediaries in Madinah City in Saudi Arabia. While the results of research conducted by Wang (2016) in Taiwan's public sector revealed that performance expectancy, effort expectancy, and social influence significantly influenced the behavioral intention of e-learning, behavioral intention and facilitating conditions significantly influenced user behavior for e-learning systems. Following previous studies, the UTAUT model is appropriate for explaining the adoption of cloud computing from an individual perspective, namely government employees. 


\section{The Security Concept of the CIA Triad}

The CIA (Confidentiality, Integrity, and Availability) is the famous security triangle that must be met by every use of information system (Chaeikar, Jafari, Taherdoost, \& Chaei Kar, 2012). It is following Qadir and Quadri (2016), who stated that everything in information security revolves around these three security attributes, namely Confidentiality, Integrity, and Availability. Based on Tsiakis and Sthephanides (2005), three elements of $\mathrm{ClA}$ security are explained as follows (1) Confidentiality is the prevention of unauthorized parties to capture, interpret, or understanding data (2) Integrity is assuredness that data have not been altered or manipulated by unauthorized parties, and (3) Availability is continuously and uninterrupted provision of services. Hartono, Kim, Na, Simpson, and Berkowitz (2013) used this concept to investigate security factors as a second-order that influenced the actual use of e-commerce in Seoul, South Korea. In this study, the security triangle was employed to explain the specific security factors that could affect the adoption of cloud computing in local government employees directly. Identifying security factors is an essential part of adopting cloud computing because cloud computing involves vendors (service providers) who have opportunistic behavior towards user information (Yigitbasioglu, 2014). Therefore, in this research, the three elements of security factors were included in the research model to describe the determinants of cloud computing adoption in local government in Indonesia.

\section{Research Model and Hypotheses Development}

Based on the UTAUT framework (Venkatesh et al., 2003) and the CIA security concept (Tsiakis \& Sthephanides, 2005; Hartono et al., 2014), this study proposed six constructs that have a direct effect on behavioral intentions (intention to use) and two constructs that have a direct effect on adoption (actual use). This study used the UTAUT model as it able to explain the characteristics of individuals Dwivedi, Rana, Jeyaraj, Clement, and Williams (2017), especially in the context of cloud computing adoption in the local government employees.

As explained by Hossain, Quaresma, and Rahman (2019), the UTAUT model can clarify as much as $70 \%$ of the variation in the intention. In the context of government, the UTAUT model has been used to provide an understanding of IS (Saxena \& Janssen, 2017; Wang, 2016; Weerakkody et al., 2013). This research model included three security factors from Tsiakis and Sthephanides (2005) and Hartono et al. (2014) to explain the adoption of cloud computing in the government. Based on the theoretical background and the review of findings in the literature, this study proposed a research model, as shown in Figure 1.

\section{Performance Expectancy}

Performance expectancy refers to the degree she/he believes that using the system will help in attaining gains in job performance (Venkatesh et al., 2003). According to Ooi et al. (2018), performance expectancy is the same variables as Perceived Usefulness in 
TAM (Technology Acceptance Model) by Davis (1989). Venkatesh et al. (2003) explained that the performance expectancy constructs within each model are the strongest predictor of intention in both voluntary and mandatory conditions.

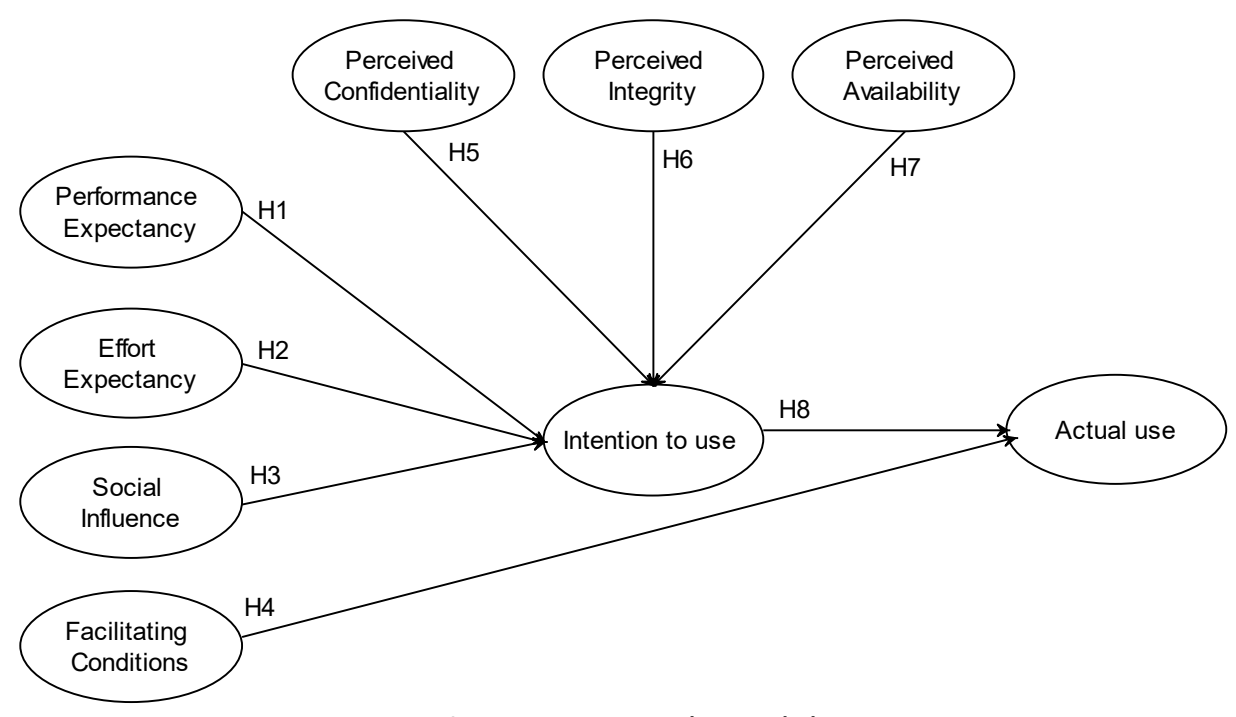

Figure 1 Research Model

In the context of government employees, previous studies found that performance expectancy played a crucial role in individual-level IT adoption such as e-government services in KSA (Kingdom of Saudi Arabia) (Alshehri, Drew, \& AlGhamdi, 2013), egovernment services in Greece (Voutinioti, 2013) and e-government in Madinah City in Saudi Arabia (Weerakkody et al., 2013). Abeywickrama and Rosca (2015) explained that for individuals, cloud computing means accessing web-based e-mail, social media platforms, and peer to peer file sharing. Mohammed et al. (2016) explained that cloud computing is useful in the way of implementing effective e-government services. The use of cloud computing in the government can improve the performance of the local government employees through the ability to be used everywhere (Jemmy, 2014). These benefits help employees for administrative processes in serving various stakeholders, like FAQ, e-procurement, and the provision of sites and locations on the local government website (Ahmad \& Hasibuan, 2012). Good service through the use of cloud computing can improve the performance of local government employees so that it can affect behavioral intention. Thus,

$\boldsymbol{H}_{1}$ : Performance expectancy positively affects the intention to use of cloud computing in the local government employees.

\section{Effort Expectancy}

Effort expectancy is one of the characteristics of technology acceptance proposed from constructs, such as ease of use, complexity, and perceived ease of use (Weerakkody et al., 2013). It refers to the degree of ease associated with the use of the system 
(Venkatesh et al., 2003). A study by Voutinioti (2013) stated that effort expectancy is a crucial driver influencing directly the user's intention to use e-government. Other research conducted by Weerakkody et al. (2013) showed that effort expectancy had a significant relationship to intention to use e-government. Effort expectancy involves the government's employees' skills to operate the system (Saxena \& Janssen, 2017). In the context of government, the easier the local government employees perceive to learn and use cloud computing, the higher the intention to use cloud computing. Therefore, it was proposed that:

$\boldsymbol{H}_{2}$ : Effort expectancy positively affects the intention to use cloud computing in the local government employees.

\section{Social Influence}

Social influence is a direct antecedent of behavioral intention (Oliveira et al., 2014). Venkatesh et al. (2003) define social influence as the degree to which an individual perceives that important others believe he or she should use the new system. In the context of government, Alraja (2016) revealed that the government employees would have a strong intention to adopt the e-government if the influence was coming from important people (for example, family, friends, and peers). The previous study conducted by Rabaa'i (2017) showed that social influence had a significant effect on the adoption of e-government services in Jordan. Therefore, the hypothesis proposed is:

$\boldsymbol{H}_{3}$ : Social influence positively affects the intention to use cloud computing in local government employees.

\section{Facilitating Condition}

Facilitating conditions is defined as the degree to which an individual believes that organizational and technical infrastructure exists to support the use of the system (Venkatesh et al., 2003). Facilitating conditions are considered to have a direct effect on technology adoption (Oliveira et al., 2014). Cloud computing use in local government requires several considerations as a high Internet network and the employees' competencies and knowledge. Therefore, the more fulfilled the infrastructure availability, the higher the level of cloud computing adoption in the local government. Gupta, Dasgupta, and Gupta (2008) revealed that facilitating conditions positively influenced ICT adoption in the government environment. A recent study conducted by (Alraja, 2016) found that facilitating conditions had a significant positive influence on the employees to adopt electronic government. Therefore, the hypothesis proposed is:

$\boldsymbol{H}_{4}$ : Facilitating conditions positively affect the adoption of cloud computing in local government employees. 


\section{Perceived Confidentiality}

Confidentiality is the prevention of unauthorized parties to capture, interpret, or understanding data (Tsiakis \& Sthephanides, 2005). This study investigated the influence of perceived confidentiality on the behavioral intentions of government employees to use cloud computing. Therefore, the definitions from Hartono et al. (2014) were used that perceived confidentiality is government employees' belief if his/her data will not be disclosed to an unauthorized party. A recent study by Aryani, Herwanti, and Basuki (2018) showed that perceived confidentiality had a positive and significant effect on interest in using e-filing. In the context of cloud computing, perceived confidentiality indicates the users' trust toward vendors (service providers) that can prevent incorrect information or data revealing. Vendors that can ensure the local government's information and data confidentiality will produce trusts that are making the local government employees interested to use cloud computing. Therefore, the hypothesis proposed is:

$\boldsymbol{H}_{5}$ : Perceived confidentiality positively affects the intention to use cloud computing in local government employees.

\section{Perceived Integrity}

Other important security factors in the use of a system are integrity. Integrity is assuredness that data have not been altered or manipulated by unauthorized parties (Tsiakis \& Sthephanides, 2005). Perceived integrity is that government employees believe that his/her data will not be altered by an unauthorized party (Hartono et al., 2014). Deventer, Klerk, and Bevan-Dye (2017) revealed that perceived integrity had a significant positive influence on an individual's trust in a system. In the context of cloud computing, perceived integrity shows the government employees' trust toward vendors that can guarantee information authenticity. The higher the vendors' ability to prevent unauthorized data modification or changes, the higher the local government employees' trusts affecting their intention to use cloud computing. Therefore, the hypothesis proposed is:

$\boldsymbol{H}_{6}$ : Perceived integrity positively affects the intention to use cloud computing in local government employees.

\section{Perceived Availability}

Availability means continuously and uninterrupted provision of services (Tsiakis \& Sthephanides, 2005). Whereas, perceived availability is government employees' belief about the service provider's ability and willingness to make information available to authorized subjects when required (Hartono et al., 2014). Perceived availability indicates the local government's thrust towards cloud computing competencies that can provide data and information punctually. Data and information availability become an 
interesting matter in the local government to provide a good information service to various stakeholders. Pross (2016) describes cloud computing's feature is to provide information and data punctually whenever users demand it through the Internet aids. Therefore, the high availability of information can influence the local government employees' intention to use cloud computing. Thus, this study proposed,

$\boldsymbol{H}_{7}$ : Perceived availability positively affects the intention to use cloud computing in local government employees.

\section{Intention to Use}

The intention is described as the extent to which a person has developed a plan to perform or not perform some specific action in future time (Udo et al., 2016). According to Ajzen (1991), behavioral intention was found to have a direct effect on actual individual usage of any information system. Many studies have used behavioral intention as an indicator that captures the motivation for actual future behavior (Udo et al., 2016). Weerakkody et al. (2013) showed that behavioral intention was a significant positive influence on the adoption of e-government services in Madinah. Other research by Rabaa'i (2017) revealed that behavioral intention had a significant effect on the adoption of e-government services in Jordan. Therefore, the hypothesis proposed is:

$\boldsymbol{H}_{8}$ : Intention to use positively affect the actual use of cloud computing in local government employees.

\section{Research Method}

This study used an online survey approach to collect the required data. Invitations via email addressed to all local government employees in Indonesia. For this reason, the invitation e-mail was sent to the official e-mail address of local government agencies in Indonesia to request permission from the relevant government authorities to distribute the online e-mail invitation to all local government employees in their organizations.

Before the main survey, this study conducted a pretest to assess logical consistencies and understanding of the item order and relevance to the questionnaires. The results of the pretest indicated that the questionnaires were clear and easily understood. After the pretest, a pilot study was performed to 32 local government employees in Sleman, aiming to assess the instrument validation and reliability before the instruments were distributed online.

This study collected official e-mail addresses manually from 542 local government agencies in Indonesia. After the e-mail addresses were contacted, some of the e-mail addresses were inactive; therefore, 334 active e-mail addresses were remaining. Two weeks after questionnaire delivery via e-mails, the questionnaires were sent back to remind respondents. Responses returned after four weeks were 127 in total. The 
response rate of the delivered questionnaires was $38 \%$. Four responses were not used due to information incompleteness resulting in 123 valid responses. The valid number of 123 respondents came from 26 provinces in Indonesia.

After collecting the data, this study tested the non-response bias by comparing respondents returning questionnaires early and respondents returning questionnaires late. Goode, Lin, Tsai, and Jiang (2015) suggest that assessing the potential non-response bias is required to establish better external validity. Results of the comparison between those two groups revealed that respondents returning the questionnaires early and late did not show any meaningful difference among item values for each construct. This study also examined differences among demographic values consisted of respondents' perceptions of their ideas of cloud computing service, understanding of cloud computing, and how to use cloud computing to work. Through the results of a comparison test, it suggests that there is no non-response bias (Oliveira et al., 2014).

\section{Measurement Items}

To justify the validity of all measures, the measurement for the latent variable in the proposed model was developed from previous studies. The detailed explanation of each variable and their relevant sources are listed in Table 1.

Table 1 Summary of Variables

\begin{tabular}{|c|c|c|}
\hline Construct & Corresponding items & Item sources \\
\hline $\begin{array}{l}\text { Performances } \\
\text { Expectancy (PE) }\end{array}$ & $\begin{array}{l}\text { Performance expectancy refers to the degree she/he believes } \\
\text { that using the system will help attain gains in job } \\
\text { performance }\end{array}$ & $\begin{array}{l}\text { Venkatesh et al. } \\
\text { (2003) }\end{array}$ \\
\hline $\begin{array}{l}\text { Effort } \\
\text { Expectancy (EE) }\end{array}$ & $\begin{array}{l}\text { It refers to the degree of ease associated with the use of the } \\
\text { system }\end{array}$ & $\begin{array}{l}\text { Venkatesh et al. } \\
\text { (2003) }\end{array}$ \\
\hline $\begin{array}{l}\text { Social } \\
\text { Influence (SI) }\end{array}$ & $\begin{array}{l}\text { social influence as the degree to which an individual } \\
\text { perceives that important others believe he or she should use } \\
\text { the new system }\end{array}$ & $\begin{array}{l}\text { Venkatesh et al. } \\
\text { (2003) }\end{array}$ \\
\hline $\begin{array}{l}\text { Facilitating } \\
\text { Conditions (FC) }\end{array}$ & $\begin{array}{l}\text { Facilitating conditions is defined as the degree to which an } \\
\text { individual believes that organizational and technical } \\
\text { infrastructure exists to support the use of the system }\end{array}$ & $\begin{array}{l}\text { Venkatesh et al. } \\
\text { (2003) }\end{array}$ \\
\hline $\begin{array}{l}\text { Perceived } \\
\text { Confidentiality (PC) }\end{array}$ & $\begin{array}{l}\text { It refers to the degree of which an individual perceives that } \\
\text { his/her data will not be disclosed to an unauthorized party }\end{array}$ & $\begin{array}{l}\text { John (1984); Silic } \\
\text { dan Back (2015) }\end{array}$ \\
\hline $\begin{array}{l}\text { Perceived } \\
\text { Integrity (PI) }\end{array}$ & $\begin{array}{l}\text { It refers to the degree of which an individual perceives that } \\
\text { his/her data will not be altered by an unauthorized party }\end{array}$ & $\begin{array}{l}\text { Cockburn dan } \\
\text { Wilson (1996); } \\
\text { Silic dan Back } \\
\text { (2015) }\end{array}$ \\
\hline $\begin{array}{l}\text { Perceived } \\
\text { Availability (PA) }\end{array}$ & $\begin{array}{l}\text { It refers to the degree of which an individual perceives that } \\
\text { the service provider's ability and willingness to make } \\
\text { information available to authorized subjects when required }\end{array}$ & $\begin{array}{l}\text { Wu, Li dan Fu } \\
\text { (2011); Silic dan } \\
\text { Back (2015) }\end{array}$ \\
\hline $\begin{array}{l}\text { Intention } \\
\text { to use (IU) }\end{array}$ & $\begin{array}{l}\text { The intention to use a system is measured by the interests, } \\
\text { predictions, and plans of individuals to use a system in the } \\
\text { future }\end{array}$ & $\begin{array}{l}\text { Venkatesh et al. } \\
\text { (2003) }\end{array}$ \\
\hline $\begin{array}{l}\text { Actual } \\
\text { use }(\mathrm{AU})\end{array}$ & The individual intention to continue to use a system & $\begin{array}{l}\text { Venkatesh et al. } \\
\text { (2003) }\end{array}$ \\
\hline
\end{tabular}

Research sample characteristics are displayed in Table 2, Table 3 (respondents' agency), and Table 4 (respondents' agency location). 
Salam \& Ali

Determining Factors of Cloud Computing Adoption: ...

Table 2 Survey Distribution to Respondents

\begin{tabular}{|c|c|c|}
\hline & Information & Percentage ( $n=123)$ \\
\hline \multirow[t]{2}{*}{ Gender1 } & Male & 72.4 \\
\hline & Female & 27.6 \\
\hline \multirow[t]{4}{*}{ Age } & 20-30 years-old & 22.0 \\
\hline & $31-40$ years-old & 51.2 \\
\hline & $41-50$ years-old & 23.6 \\
\hline & $50-60$ years-old & 3.3 \\
\hline \multirow[t]{6}{*}{ Position } & Office head & 2.4 \\
\hline & Office secretary & 0.8 \\
\hline & Money treasurer & 0.8 \\
\hline & Division head & 8.1 \\
\hline & Sub-division head & 25.2 \\
\hline & Staff & 62.6 \\
\hline \multirow{4}{*}{$\begin{array}{l}\text { Working } \\
\text { experience }\end{array}$} & $\leq 1$ year & 16.3 \\
\hline & $1>X \geq 3$ years & 43.9 \\
\hline & $3>x \geq 6$ years & 13.0 \\
\hline & $>6$ years & 26.8 \\
\hline \multirow{3}{*}{$\begin{array}{l}\text { Educational } \\
\text { level }\end{array}$} & Diploma & 16.3 \\
\hline & Bachelor & 56.9 \\
\hline & Post Graduate & 26.8 \\
\hline \multirow{9}{*}{$\begin{array}{l}\text { Used } \\
\text { application }\end{array}$} & Google drive & 71.5 \\
\hline & Dropbox & 41.5 \\
\hline & Gmail & 81.3 \\
\hline & Yahoo mail & 47.2 \\
\hline & Amazon web service & 1.6 \\
\hline & Windows Azure & 1.6 \\
\hline & Microsoft Azure & 0.8 \\
\hline & Urban mapping & 4.9 \\
\hline & Other applications & 13.0 \\
\hline
\end{tabular}

Table 3 Respondents' Agency

\begin{tabular}{lc}
\hline Agency & Percentage (n=123) \\
\hline Communication and Information Office & 68 \\
Education Office & 3 \\
Environment and Forest Office & 3 \\
Transportation Office & 3 \\
Industry and Trade Office & 3 \\
Office for Management of Regional Revenue, Finance, and Assets & 3 \\
Regional Revenue Management Agency & 3 \\
Regional Secretary & 2 \\
Regional Education and Training Civil Agency & 2 \\
Investment and One-stop Integrated Service Office & 2 \\
Office of Public Works and Spatial Planning & 2 \\
Health Office & 2 \\
Office of Community Empowerment & 1 \\
Livestock and Agricultural Office & 1 \\
\hline
\end{tabular}


Table 4 Respondents' Agency Origin

\begin{tabular}{lc} 
Respondents' Agency Origin & Percentage (n) \\
\hline Central Java & 29 \\
South Sulawesi & 22 \\
Riau & 6 \\
Banten & 5 \\
West Java & 5 \\
North Sumatera & 5 \\
\hline Aceh & 3 \\
Southeast Sulawesi & 3 \\
Bengkulu & 2 \\
East Java & 2 \\
Maluku & 2 \\
Jakarta & 2 \\
Yogyakarta & 2 \\
Central Kalimantan & 2 \\
Jambi & 1 \\
East Kalimantan & 1 \\
Kepulauan Bangka Belitung & 1 \\
Kepulauan Riau & 1 \\
Lampung & 1 \\
North Maluku & 1 \\
West Nusa Tenggara & 1 \\
East Nusa Tenggara & 1 \\
West Papua & 1 \\
Central Sulawesi & 1 \\
West Sumatera & 1 \\
South Sumatera & 1 \\
\hline
\end{tabular}

\section{Result and Discussion}

The demographic features of the respondents are presented in Table 2. For the surveys analyzed, $89(72.4 \%)$ respondents are males, and $34(27.6 \%)$ are females. The majority of the respondents (51.2\%) were aged between 31 and 40 years. Besides, 62.6 of the respondents were staff (directly users). Moreover, 54 of the respondents had more than three years become a government employee, and 100 respondents of 123 had used Gmail. The research model was analyzed using structural equation modeling, i.e., by using two method stages in the PLS (Partial Least Square) analysis, started by a measurement model to test instrument reliability and validity and to analyze structural models (Anderson \& Gerbing 1988). This research employed PLS since cloud computing in public sector organizations in Indonesia was in the early stage so that data would not be normally distributed. Hair, Sarstedt, Ringle, and Mena (2012) stated that PLS was a correct analysis method used in such a condition. 


\section{Measurement Model}

The results of the measurement model analysis are presented in Table 5. Composite reliability (CR) and Cronbach's alpha (CA) indicated that all constructs had a value of more than 0.70 , suggesting that measurement used satisfied the internal consistency (Table 5). Average Variance Extracted (AVE) and outer loading was utilized to test convergent validity. A construct was valid in the convergent validity of the outer loading value was more than 0.70 (Chin, 1998), and the AVE value was more than 0.50 (Jr Hair, Black, Babin, \& Anderson, 2014). Meanwhile, discriminant validity assessed based on the AVE root was more than the latent variable correlation (Table 5) and intervariable correlation coefficient (Table 6). The reliability test in PLS can be measured by looking at the value of Cronbach's alpha and composite reliability. Table 5 shows the Cronbach's alpha value, and the composite reliability of each construct is above 0.7 . Thus, it can be concluded that the measurement used in this study was reliable. Based on Tables 5 and 6 , all constructs met both validity and reliability criteria in the PLS analysis. Hence, they could be used to test the structural model.

Table 5 Item Loadings, AVE, AVE Root, CR, and CA

\begin{tabular}{|c|c|c|c|c|c|c|}
\hline & Item & Loadings & AVE & $\begin{array}{l}\text { AVE } \\
\text { Root }\end{array}$ & $\begin{array}{l}\text { Composite } \\
\text { Reliability }\end{array}$ & $\begin{array}{c}\text { Cronbach's } \\
\text { Alpha }\end{array}$ \\
\hline \multirow[t]{4}{*}{ Performance Expectancy (PE) } & PE1 & 0.838 & 0.729 & 0.854 & 0.914 & 0.875 \\
\hline & PE2 & 0.889 & & & & \\
\hline & PE3 & 0.896 & & & & \\
\hline & PE4 & 0.787 & & & & \\
\hline \multirow[t]{4}{*}{ Effort Expectancy (EE) } & EE1 & 0.764 & 0.721 & 0.849 & 0.911 & 0.871 \\
\hline & EE2 & 0.851 & & & & \\
\hline & EE3 & 0.897 & & & & \\
\hline & EE4 & 0.879 & & & & \\
\hline \multirow[t]{3}{*}{ Social Influence (SI) } & SI1 & 0.741 & 0.756 & 0.869 & 0.902 & 0.834 \\
\hline & $\mathrm{SI} 2$ & 0.934 & & & & \\
\hline & SI3 & 0.921 & & & & \\
\hline \multirow[t]{3}{*}{ Facilitating Condition (FC) } & FC1 & 0.761 & 0.626 & 0.791 & 0.834 & 0.703 \\
\hline & $\mathrm{FC2}$ & 0.814 & & & & \\
\hline & $\mathrm{FC} 3$ & 0.799 & & & & \\
\hline \multirow[t]{3}{*}{ Perceived Confidentiality (PC) } & PC1 & 0.885 & 0.771 & 0.878 & 0.909 & 0.865 \\
\hline & PC2 & 0.829 & & & & \\
\hline & PC3 & 0.917 & & & & \\
\hline \multirow[t]{3}{*}{ Perceived Integrity (PI) } & $\mathrm{PI} 1$ & 0.931 & 0.852 & 0.923 & 0.945 & 0.915 \\
\hline & $\mathrm{PI} 2$ & 0.927 & & & & \\
\hline & $\mathrm{PI3}$ & 0.910 & & & & \\
\hline \multirow[t]{3}{*}{ Perceived Availability (PA) } & PA1 & 0.882 & 0.803 & 0.896 & 0.924 & 0.878 \\
\hline & PA2 & 0.889 & & & & \\
\hline & PA3 & 0.916 & & & & \\
\hline \multirow[t]{3}{*}{ Intention to Use (IU) } & IU1 & 0.918 & 0.873 & 0.934 & 0.953 & 0.928 \\
\hline & IU2 & 0.938 & & & & \\
\hline & IU3 & 0.947 & & & & \\
\hline \multirow[t]{3}{*}{ Adoption (AU) } & AU1 & 0.874 & 0.773 & 0.879 & 0.911 & 0.853 \\
\hline & AU2 & 0.898 & & & & \\
\hline & AU3 & 0.865 & & & & \\
\hline
\end{tabular}


Determining Factors of Cloud Computing Adoption: ...

Table 6 Latent Variable Correlation

\begin{tabular}{lrrrrrrrrr}
\hline & AU & EE & FC & IU & PA & PC & PE & PI & SI \\
\hline AU & 1.000 & & & & & & & & \\
EE & 0.569 & 1.000 & & & & & & & \\
FC & 0.498 & 0.537 & 1.000 & & & & & & \\
IU & 0.805 & 0.582 & 0.534 & 1.000 & & & & & \\
PA & 0.687 & 0.564 & 0.485 & 0.624 & 1.000 & & & & \\
PC & 0.369 & 0.361 & 0.300 & 0.313 & 0.521 & 1.000 & & & \\
PE & 0.528 & 0.524 & 0.376 & 0.499 & 0.461 & 0.130 & 1.000 & & \\
PI & 0.367 & 0.419 & 0.328 & 0.359 & 0.543 & 0.835 & 0.215 & 1.000 & \\
SI & 0.384 & 0.554 & 0.602 & 0.360 & 0.396 & 0.398 & 0.339 & 0.400 & 1.000 \\
\hline
\end{tabular}

\section{Structural Model}

The structural model in PLS was evaluated by using R2 for the dependent variables while utilizing the coefficient value and path $(\beta)$ for the independent variables (Hair et al., 2012). Then, the independent variables' significance level was assessed based on the Tstatistic of each path. The structural model of this research is presented in Figure 2. In contrast, the results of the path coefficient are presented in Table 7. Based on the values of the beta coefficient and T-statistic, test results for each hypothesis are as follows.

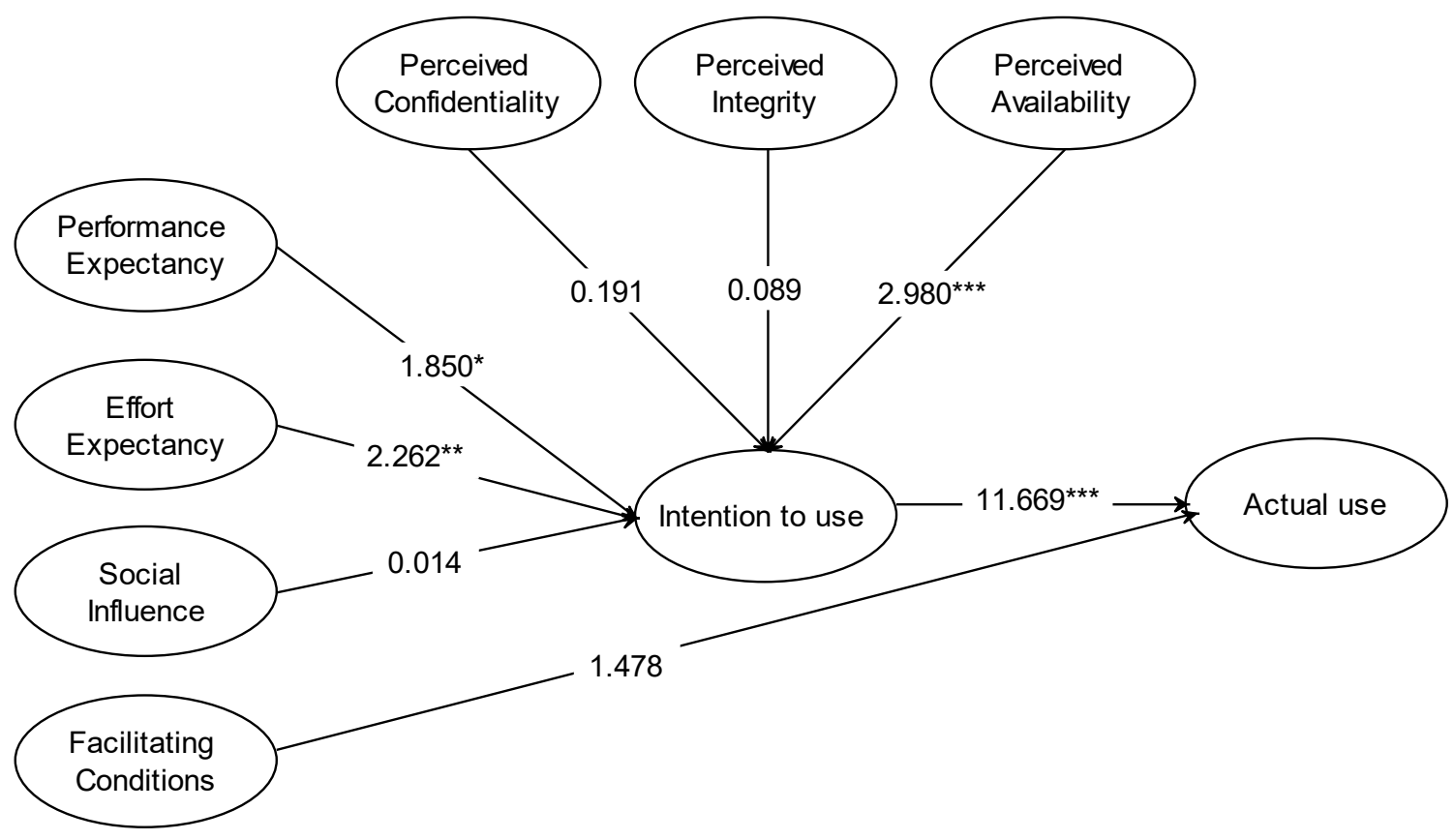

Note: Statistically significant at $* p<0.1, * * p<0.05, * * * p<0.01$

Figure 2 Structural Model Results 
Salam \& Ali

Determining Factors of Cloud Computing Adoption: ...

Table 7 Path Coefficient Results on Structural Model

\begin{tabular}{lcccccl}
\hline & $\begin{array}{c}\text { Original } \\
\text { Sample (O) }\end{array}$ & $\begin{array}{c}\text { Sample } \\
\text { Mean (M) }\end{array}$ & $\begin{array}{c}\text { Standard } \\
\text { Deviation } \\
\text { (STDEV) }\end{array}$ & $\begin{array}{c}\text { Standard } \\
\text { Error } \\
\text { (STERR) }\end{array}$ & $\begin{array}{c}\text { T Statistics } \\
\text { (|O/STERR|) }\end{array}$ \\
\hline $\mathrm{H} 1$ & $\mathrm{PE} \rightarrow \mathrm{IU}$ & 0.175781 & 0.18481 & 0.09502 & 0.09502 & $1.849948^{*}$ \\
$\mathrm{H} 2$ & $\mathrm{EE} \rightarrow \mathrm{IU}$ & 0.269783 & 0.2733 & 0.119272 & 0.119272 & $2.261907^{* *}$ \\
$\mathrm{H} 3$ & $\mathrm{SI} \rightarrow \mathrm{IU}$ & -0.001212 & 0.00953 & 0.087899 & 0.087899 & 0.013792 \\
$\mathrm{H} 4$ & $\mathrm{FC} \rightarrow \mathrm{AU}$ & 0.09509 & 0.09856 & 0.064348 & 0.064348 & 1.477753 \\
$\mathrm{H} 5$ & $\mathrm{PC} \rightarrow \mathrm{IU}$ & -0.02531 & -0.0157 & 0.132511 & 0.132511 & 0.191007 \\
$\mathrm{H} 6$ & $\mathrm{PI} \rightarrow \mathrm{IU}$ & 0.014214 & 0.00763 & 0.160605 & 0.160605 & 0.088503 \\
$\mathrm{H} 7$ & $\mathrm{PA} \rightarrow \mathrm{IU}$ & 0.39672 & 0.38755 & 0.133134 & 0.133134 & $2.979861^{* * *}$ \\
$\mathrm{H} 8$ & $\mathrm{IU} \rightarrow$ AU & 0.754081 & 0.75493 & 0.064625 & 0.064625 & $11.66853^{* * *}$ \\
\hline $\mathrm{N}$
\end{tabular}

Note: Statistically significant at $* p<0.1, * * p<0.05, * * * p<0.01$

\section{Discussion}

As posited, the relationship between performance expectancy $(\mathrm{H} 1)$ to the intention to use cloud computing by local government employees was found to be significant. This result is consistent with findings from other researchers who have validated the significant role of performance expectancy and effort expectancy in IT adoption (Venkatesh et al., 2003; Alshehri et al., 2013; Azidin, Romle, \& Mansor, 2015; Rabaa'i, 2017). The characteristics of Indonesia by using a sectoral-regional approach led to the formation of the central government and local governments (Ahmad \& Hasibuan, 2012). Due to the approach, the local government employees need to use information systems that make them easier to share and consolidate data with various stakeholders while increasing efficiency and effectiveness at work. As we know that cloud computing can simplify, optimize, and integrate government administration and service, and achieve various business processes and services by informatization (Liang et al., 2017). Therefore, the performance expectancy has influenced intentions to use cloud computing by local government employees in Indonesia.

Effort expectancy $(\mathrm{H} 2)$ was revealed to have a positive effect on the intention to use cloud computing by local government employees, which is consistent with a past adoption study of e-government (Voutinioti, 2013). Cloud computing was easy to learn and use so that the intention to use by government employees tended to be higher. As cloud computing involves service providers (Yigitbasioglu, 2014) and the concept of pay as you go (Sallehudin et al., 2015), it does not require much effort to use by local government employees. Also, the use of cloud computing was felt more accessible by local government employees because they had previous experience using cloud-based technology. It is shown by Hermana and Silfianti (2011) that there were 150 local government webs, or approximately $82.9 \%$ can be accessed.

Social influence (H3) did not affect the intention to use cloud computing in local government employees. It might be due to the low level of awareness of cloud computing in Indonesia (Chandrasekaran \& Kapoor, 2011). Consequently, the finding of this study is inconsistent with previous studies on the adoption of e-government in the Sultanate of Oman (Alraja, 2016), and e-government in Malaysia (Azidin et al. 2015). The 
other possible explanation was due to the use of cloud computing in government was not a mandatory policy. The adoption of cloud computing in the local government employees is not mandatory to use. Ahmad and Hasibuan (2012) stated that the lack of rules prevents the Indonesian government from adopting cloud computing. Further, Venkatesh et al. (2003) suggested that social influence could be a significant factor in the environment, which required people to use a particular system.

Facilitating conditions ( $\mathrm{H} 4)$ did not affect the actual use of cloud computing. The possible explanation might be the limitation of IT resources in each local government in Indonesia that did not prevent the employee from using cloud-computing services. It means that the supporting sources for adopting cloud computing are not deemed necessary for employee the local government in Indonesia. Cloud computing services do not require sophisticated IT infrastructures. It only needs a reliable computer connected to the internet. Although the high-speed internet network infrastructure is still not common and specifically available in the local government in Indonesia (Ahmad \& Hasibuan, 2012), it seems local government employees still able to access cloud computing services. However, this phenomenon may also be related to the fact that most of the cloud-computing services accessed by the Indonesian local government employee were free software-as-a-service cloud computing types that did not require a high level of technical support and knowledge capability.

Perceived security was a crucial part of new information technology use. This research expanded factors influencing cloud computing adoption in the context of government. The findings of this study showed both security factors, namely perceived confidentiality (H5) and perceived integrity ( $\mathrm{H6}$ ), did not affect the intention of using cloud computing in the local government employees. Although perceived confidentiality and perceived integrity have been predicted to be able to affect the intention of local government employees to use cloud computing, the results were different. The possible explanation for this finding might be due to the low awareness of local government employees on cloud computing adoption (Chandrasekaran \& Kapoor, 2011), which is in accordance with Carnall (2017) that the awareness positively influenced individual intentions. One other reason, which caused the hypothesis proposed was not supported, was because the use of cloud computing was not for confidential and vital data by local government employees. Therefore, confidentiality and integrity did not affect the intention to use cloud computing.

The findings of this study also confirm that perceived availability (H7) had a positive association with intention to use cloud computing. Among the three security factors, perceived availability is a factor that influences the adoption of cloud computing in local government employees. This finding explains that the local government employees considered cloud computing to have the ability to provide data and information faster when needed (on demand). The previous study conducted by Susanto and Goodwin (2010) showed that perceived availability affected the adoption of SMS-Based eGovernment Services. 
The findings also revealed that behavioral intention (intention to use) (H8) is essential for cloud computing adoption (actual use) by local government employees. This result showed that the intention to use cloud computing positively and significantly influenced the actual use by a local government employee in Indonesia. It is in line with past studies of IT adoption, such as Information Technology (Venkatesh et al., 2003) and mBanking adoption (Oliveira et al., 2014). In the context of government, the intention of use also affected significantly on actual use, such as e-Government (Voutinioti, 2013; Weerakkody et al., 2013).

\section{Conclusion}

This study identifies three determinants of cloud computing adoption by local government: performance expectancy, effort expectancy, and perceived availability. In addition, this research revealed perceived availability influenced the intention to use cloud computing in Indonesian local government employees, which is consistent with Information Security Control Theory (Anderson, Baskerville, \& Kaul, 2017). The theory outlines that the information systems are inherently exposed to threats so that the exposure control reasoning aims to manage these risk exposures. Perceived availability can be used for viewing IT security control from an individual perspective.

The results of this study provide important implications for decision-makers, IT departments, and local government practitioners. In developing cloud computing initiatives, the findings of this research would be beneficial for the initiator of cloud computing in the Indonesian public sector. The initiator of cloud computing can understand the key factors that must be considered for cloud computing adoption so that other government organizations can accept the implementation of cloud computing in the future. Further, top management can use the research findings as inputs to develop the strategy, guidelines, and procedure of cloud computing adoption by understanding the influential determinants of cloud computing adoption in their organization. Moreover, the study also helps the service provider to create the appropriate types of cloud computing in governments organization.

The context of this study was restricted to Indonesian local government employees. The local government employees have their characteristics, and it is different from other government employees in the central government. This study did not represent the cloud computing adoption determinants across government organizations more generally. Therefore, multi-group analyses may need to be conducted to examine the differences among the type of government (e.g., local government, central government) (Haneem, Kama, Taskin, Pauleen, \& Bakar, 2019).

Moreover, this study had some limitations as it only used a small sample size. Consequently, the results cannot be generalized to local governments in Indonesia. Using large sample sizes might allow for a better explanation of cloud computing adoption by local government employees. Further, the results of the study revealed that social influence, facilitating conditions, perceived confidentiality, and perceived integrity 
had no influence on the adoption of cloud computing by local government employees. It is recommended for future research to introduce the moderator variable to the relationship between those variables in cloud computing adoption.

\section{References}

Abeywickrama, M., \& Rosca, V. (2015). Public Organizations Flying in the Cloud : A Case Study of Cloud Computing Value Creation in Moldova. Master Thesis. Department of informatics, Universitet UMEA. Retrieved from https://www.divaportal.org/smash/get/diva2:821622/FULLTEXT01.pdf

Ahmad, M., \& Hasibuan, Z. A. (2012). E-Government Based on Cloud Environment in Indonesia. Seminar Nasional Aplikasi Teknologi Informasi 2012 (SNATI). Retrieved from https: $/ /$ www.google.com/url? $\mathrm{sa}=\mathrm{t} \& \mathrm{rct}=\mathrm{i} \& \mathrm{q}=\& \mathrm{esrc}=\mathrm{s} \& \mathrm{source}=\mathrm{web} \& \mathrm{~cd}=2 \& \mathrm{cad}=\mathrm{rja}$ \&uact=8\&ved=2ahUKEwj42Orz7ZzpAhUt7XMBHYIwCFoQFjABegQIAhAB\&url $=$ https $\% 3 \mathrm{~A} \% 2 \mathrm{~F} \% 2 \mathrm{Fjournal}$.uii.ac.id $\% 2 \mathrm{FSnati} \% 2 \mathrm{Farticle} \% 2 \mathrm{Fdownload} \% 2 \mathrm{~F} 2893 \% 2 \mathrm{~F}$ 2652\&usg=AOvVaw0FcuM2zKrG7k4ogFcFDvdg

Ajzen, I. (1991). The Theory of Planned Behavior. Organizational Behavior and Human Decision Processes, 50(2), 179-211. https://doi.org/10.1016/0749-5978(91)90020-t

Alassafi, M, O., Alharthi, A., Walters, R. J., \& Wills, G. B. (2017). A Framework for Critical Security Factors That Influence the Decision of Cloud Adoption by Saudi Government Agencies. Telematics and Informatics, 34, 996-1010. https://doi.org/10.1016/j.tele.2019.04.003

Alraja, M. N. (2016). The Effect of Social Influence and Facilitating Conditions on EGovernment Acceptance From the Individual Employees' Perspective. Polish Journal of Management Studies, 14(2), 18-27. https://doi.org/10.17512/pims.2016.14.2.02

Al-Rashedi, A. A. (2014). E-Government Based on Cloud Computing and Service-Oriented Architecture. International Journal of Computer and Electrical Engineering, 6(3), 201-206. https://doi.org/10.7763/ijcee.2014.v6.822

Al-Ruithe, M., Benkhelifa, E., \& Hameed, K. (2017). Current State of Cloud Computing Adoption - An Empirical Study in Major Public Sector Organizations of Saudi Arabia (KSA). Procedia Computer Science, 110, 378-385. https://doi.org/10.1016/i.procs.2017.06.080

Alshehri, M., Drew, S., \& AlGhamdi, R. (2013). Analysis of Citizens Acceptance for EGovernment Services: Applying the UTAUT Model. International Conference Theory and Practice in Modern Computing and Internet Applications and Research, 69-76. Retrieved from https://arxiv.org/abs/1304.3157

Anderson, C., Baskerville, R. L., \& Kaul, M. (2017). Information Security Control Theory: Achieving a Sustainable Reconciliation between Sharing and Protecting the Privacy of Information. Journal of Management Information Systems, 34(4), 1082-1112. https://doi.org/10.1080/07421222.2017.1394063

Anderson, J. C., \& Gerbing, D. W. (1988). Structural Equation Modeling in Practice: A Review and Recommended Two-Step Approach. Psychological Bulletin, 103(3), 411-423. https://doi.org/10.1037/0033-2909.103.3.411

Aryani, R. A. I., Herwanti, R. T., \& Basuki, P. (2018). The Effect of Perception of Use, Ease, Security, and Confidentiality to Use E-Filing (Study In The Tax Office Pratama Raba Bima). International Journal of Scientific Research and Management, 6, 4, 294-304. https://doi.org/10.18535/ijsrm/v6i4.em08 
Azidin, S.S., Romle, A. R., \& Mansor, M. H. (2015). Overarching Unified Theory of Acceptance and Use of Technology(Utaut) Model on The Factors Effecting Behavioral Intention Towards E-Government Adoption in Malaysia. International Journal of Administration and Governance, 1(10), 106-110.

Bourne, J. (2018). Alibaba Cloud Opens up First Indonesian Data Centre. CLOUDTECH. Retrieved from https://www.cloudcomputing-news.net/news/2018/mar/16/alibabacloud-opens-first-indonesian-data-centre/

BSA, The Software Alliance. (2018). Indonesia Falls in Updated BS A Global Cloud Computing Scorecard 's Rankings. Retrieved from https: / $/$ www.google.com/url? sa $=$ t\&rct $=i \& q=\& e s r c=s \& s o u r c e=w e b \& c d=2 \& c a d=r j a$ \&uact $=8 \& v e d=2$ ahUKEwi5o5Oe8ZzpAhWPeX0KHU1NDxgQFjABegQIARAB\&u $\mathrm{rl}=\mathrm{https} \% 3 \mathrm{~A} \% 2 \mathrm{~F} \% 2 \mathrm{~F}$ cloudscorecard.bsa.org $\% 2 \mathrm{~F} 2018 \% 2 \mathrm{Fpdf} \% 2 \mathrm{FBSA} 2018$ Glob al Cloud Scorecard.pdf\&usg=AOvVaw36piaQO1 eitgYy2MNXKp9

Carnall, C. (2017). Awareness, Attitude, and Purchase Intention's Influence on the Response to the Out of Stock of Organic Yogurts. Dissertation. Retrieved from https://repositorio.ucp.pt/bitstream/10400.14/22133/1/Msc\%20Dissertation\%20Ca rolina $\% 20$ Carnall.pdf

Chaeikar, S. S., Jafari, M., Taherdoost, H., \& Chaei Kar, N. S. (2012). Definitions and Criteria of CIA Security Triangle in Electronic Voting System. International Journal of Advanced Computer Science and Information Technology IJACSIT, 1(1), 1-10. Retrieved from http://citeseerx.ist.psu.edu/viewdoc/download?doi=10.1.1.428.9741\&rep=rep1\&typ $\underline{\mathrm{e}=\mathrm{pdf}}$

Chandrasekaran, A., \& Kapoor, M. (2011). State of Cloud Computing in the Public Sector-A Strategic Analysis of the Business Case and Overview of Initiatives Across Asia Pacific. Frost \& Sullivan.

Chin, W. W. (1998). Commentary: Issues and Opinion on Structural Equation Modeling. MIS Quarterly 22.

Davis, F.D. (1989). Perceived Usefulness, Perceived Ease of Use, and User Acceptance of Information Technology. MIS Quarterly, 13, 319-340.

Deventer, M. V., Klerk, N. D., \& Bevan-Dye, A. (2017). Influence of Perceived Integrity and Perceived System Quality on Generation Y Students' Perceived Trust in Mobile Banking in South Africa. Banks and Bank Systems, 12(1), 128-134. https://doi.org/10.21511/bbs.12(1-1).2017.05

Dwivedi, Y, K., Rana, N.P., Jeyaraj, A., Clement, M., \& Williams, M.D. (2017). ReExamining The Unified Theory of Acceptance and Use of Technology (UTAUT): Towards a Revised Theoretical Model. Information Systems Frontiers, 21 (1), 719-734. https://doi.org/10.1007/s10796-017-9774-y

Goode, S., Lin, C., Tsai, J. C., \& Jiang, J. J. (2015). Rethinking the Role of Security in Client Satisfaction with Software-as-a-Service (SaaS) Providers. Decision Support Systems, 70, 73-85. https://doi.org/10.1016/i.dss.2014.12.005

Gupta, B., Dasgupta, S., \& Gupta, A. (2008). Adoption of ICT in a Government Organization in a Developing Country: An Empirical Study. Journal of Strategic Information Systems, 17(2), 140-154. https://doi.org/10.1016/j.jsis.2007.12.004

Hair, J. F., Sarstedt, M., Ringle, C. M \& Mena, J. A. (2012). An Assessment of the Use of Partial Least Squares Structural Equation Modeling in Marketing Research. Journal of the Academy of Marketing Science, 40, 414-33. https://doi.org/10.1007/s11747-0110261-6

Haneem, F., Kama, N., Taskin, N., Pauleen, D., \& Bakar, N. A. A. (2019). Determinants of Master Data Management Adoption by Local Government Organizations : An 
Empirical Study. International Journal of Information Management, 45, 25-43. https://doi.org/10.1016/j.ijinfomgt.2018.10.007

Hartono, E., Holsapple, C. W., Kim, K.Y., Na, K.S., \& Simpson, J.T. (2014). Measuring Perceived Security in B2C Electronic Commerce Website Usage: A Respecification and Validation. Decision Support Systems, 62, 11-21.

https://doi.org/10.1016/i.dss.2014.02.006

Hartono, E., Kim, K. Y., Na, K. S., Simpson, J.T., \& Berkowitz, D. (2013). Perceived Site Security as a Second Order Construct and Its Relationship to E-Commerce Site Usage. Advances in Information Systems and Technologies, 206, 1075-1085. https://doi.org/10.1007/978-3-642-36981-0 102

Hartono, J. (2017). Membangun IT Savy Untuk. Menjadi Organisasi Digital Master (chapter 1). Yogyakarta: Penerbit Andi.

Hermana, B., \& Silfianti, W. (2011). Evaluating E-Government Implementation by Local Government: Digital Divide in Internet-Based Public Services in Indonesia. International Journal of Business and Social Science, 2(3), 156-64. Retrieved from http://www.ijbssnet.com/journals/Vol. 2 No. 3 \%5BSpecial Issue January 2011\%5D/18.pdf

Hossain, A., Quaresma, R., \& Rahman, H. (2019). Investigating Factors Influencing the Physicians' Adoption of Electronic Health Record (EHR) in the Healthcare System of Bangladesh: An Empirical Study. International Journal of Information Management, 44, 7687. https://doi.org/10.1016/j.ijinfomgt.2018.09.016

Janssen, M., \& Joha, A. (2011). Challenges for Adopting Cloud-Based Software As a Service (Saas) in the Public Sector. Proceedings of European Conference on Information Systems, ECIS, 1-12. Retrieved from http://aisel.aisnet.org/ecis2011?utm source=aisel.aisnet.org\%2Fecis2011\%2F80\&ut $\mathrm{m}$ medium $=\mathrm{PDF} \& u$ tm campaign $=\mathrm{PDFCoverPages}$

Jemmy. (2014). Leading End-to-End ICT Company in Indonesia. E-Governance and Cloud Computing. Retrieved from http://anitanet.staff.ipb.ac.id/files/2014/09/Telkom Governance-CloudComputing-V2.pdf

John, G. (1984). An Empirical Investigation of Some Antecedents of Opportunism in a Marketing Channel. Journal of Marketing Research, 21(3), 278 to 289. https://doi.org/10.1177/002224378402100305

Jones, S. (2015). Cloud Computing Procurement and Implementation: Lessons Learnt from a United Kingdom Case Study. International Journal of Information Management, 35(6), 712 716. https://doi.org/10.1016/i.ijinfomgt.2015.07.007

Jr Hair, J. F., Black, W. C., Babin, B. J, \& Anderson, R. E. (2014). Multivariate Data Analysis. Edinburg: Pearson Education Limited.

Lian, J-W., Yen, D. C., \& Wang, Y-T. (2014). An Exploratory Study to Understand the Critical Factors Affecting the Decision to Adopt Cloud Computing in Taiwan Hospital. International Journal of Information Management, 34(1), 28-36. https://doi.org/10.1016/j.ijinfomgt.2013.09.004

Liang, Y., Qi, G., Wei, K., \& Chen, J. (2017). Exploring the Determinant and Influence Mechanism of E-Government Cloud Adoption in Government Agencies in China. Government Information Quarterly, 34(3), 481-95. https://doi.org/10.1016/j.giq.2017.06.002

Macias, F., \& Thomas, G. (2011). Cloud Computing Advantages in the Public Sector. White Paper. Retrieved from http://services.igi-global.com/resolvedoi/resolve.aspx?doi=10. $\underline{4018 / 978-1-4666-8629-8 \cdot \operatorname{ch} 009}$ 
Microsoft Foundation. (2016). Modernizing the Public Sector through the Cloud. Retrieved from https://researchictafrica.net/wp/wp-content/uploads/2017/10/CloudComputing-in-the-public-sector-final-25052017_V03.pdf

Ministry of Home Affairs of the Republic of Indonesia. (2014). Pembentukan Daerah-Daerba Otonom Di Indonesia Sampai Dengan Tabun 2014. Retrieved from http://otda.kemendagri.go.id/CMS/Images/SubMenu/total daerah otonom.pdf

Mohammed, F., Ibrahim, O., \& Ithnin, N. (2016). Factors Influencing Cloud Computing Adoption for E-Government Implementation in Developing Countries: Instrument Development. Journal of Systems and Information Technology, 18(3), 297-327. https://doi.org/10.1108/jsit-01-2016-0001

NIST. (2013). NIST Cloud Computing Standards Roadmap. Retrieved from https://nvlpubs.nist.gov/nistpubs/SpecialPublications/NIST.SP.500-291r2.pdf

Oliveira, T., Faria, M., Thomas, M. A \& Popovič, A. (2014). Extending The Understanding of Mobile Banking Adoption: When UTAUT Meets TTF and ITM. International Journal of Information Management, 34(5), 689-703. https://doi.org/10.1016/i.ijinfomgt.2014.06.004

Ooi, K. B., Lee, V. H., Tan, G. W. H., Hew, T. S., \& Hew, J. J. (2018). Cloud Computing in Manufacturing: The Next Industrial Revolution in Malaysia? Expert Systems With Applications, 93, 376-94. https://doi.org/10.1016/i.eswa.2017.10.009

Pross, L. (2016). Trust in the Cloud. Master Thesis. Retrieved from http://essay.utwente.nl/71524/1/Pross MA BMS.pdf

Qadir, S., \& Quadri, S. M. K. (2016). Information Availability: An Insight into the Most Important Attribute of Information Security. Journal of Information Security, 7(3) 185-94, https://doi.org/10.4236/jis.2016.73014

Rabaa'i, A. A. (2017). The Use of UTAUT to Investigate the Adoption of E-Government in Jordan: A Cultural Perspective. International Journal of Business Information Systems, 24(3), 285. https://doi.org/10.1504/ijbis.2017.10002806

Sallehudin, H., Razak, R.C., \& Ismail, M. (2015). Factors Influencing Cloud Computing Adoption in the Public Sector: An Empirical Analysis. Journal of Entrepreneurship and Business, 3(1), 30-45. https://doi.org/10.17687/jeb.0301.03

Saxena, S., \& Janssen, M. (2017). Examining Open Government Data (OGD) Usage in India through the UTAUT Framework. Foresight, 19(4), 421-436. https://doi.org/10.1108/fs-02-2017-0003

Silic, M., \& Back, A. (2015). The Influence of Risk Factors in the Decision-Making Process for Open Source Software Adoption. International Journal of Information Technology \& Decision Making, 15(1), 151-185. https://doi.org/10.1142/s0219622015500364

Skis, T \& Sthephanides, G. (2005). The Concept of Security and Trust in Electronic Payments. Computer \& Security, 24(1), 10-15. https://doi.org/10.1016/i.cose.2004.11.001

Susanto, T. D., \& Goodwin, R. (2010). Actors Influencing Citizen Adoption of SMS-Based e-Government Services. Electronic Journal of $e$-Government, 8(1), 55-71. Retrieved from https: $/ / \mathrm{www}$. google.com/url? $\mathrm{sa}=\mathrm{t} \& \mathrm{rct}=j \& \mathrm{q}=\& \mathrm{esrc}=\mathrm{s} \& \mathrm{source}=\mathrm{web} \& \mathrm{~cd}=2 \& \mathrm{cad}=\mathrm{rja}$ \&uact $=8 \& v e d=2$ ahUKEwinga 6 Ny53pAhUYWCsKHVLCKMQFjABegQIAhAB\&url=http $\% 3 \mathrm{~A} \% 2 \mathrm{~F} \% 2 \mathrm{Fwww}$.ejeg.com $\% 2$ Fissue $\% 2 \mathrm{Fdownl}$ oad.html\%3FidArticle\%3D165\&usg=AOvVaw2tU6zrDa-SXtG3tH13XqZo

Udo, G., Bagachi, K., \& Maity, M. (2016). Exploring Factors Affecting Digital Piracy Using the Norm Activation and UTAUT Models: The Role of National Culture. Journal of Business Ethics, 135(3), 517-541. https://doi.org/10.1007/s10551-014-2484-1 
Venkatesh, V., Morris, M. G., Davis, G.B \& Davis, F.D. (2003). User Acceptance of Information Technology: Toward A Unified View. MIS Quarterly, 27(3), 425-478. https://doi.org/10.2307/30036540

Voutinioti, A. (2013). Determinants of User Adoption of E-Government Services in Greece and the Role of Citizen Service Centres. Procedia Technology, 8, 238-244. https://doi.org/10.1016/i.protcy.2013.11.033

Wang, M. H. (2016). Factors Influencing Usage of E-Learning Systems in Taiwan's Public Sector: Applying the UTAUT Model. Advances in Management \& Applied Economics, 6(6), 63-82. Retrieved from http://www.scienpress.com/Upload/AMAE\%2FVol\%206 6 5.pdf

Weerakkody, V., El-Haddadeh, R., Al-Sobhi, F., Shareef, M. A., \& Dwivedi, Y. K. (2013). Examining the Influence of Intermediaries in Facilitating E-Government Adoption: An Empirical Investigation. International Journal of Information Management, 33(5), 716725. https://doi.org/10.1016/j.ijinfomgt.2013.05.001

Yigitbasioglu, O. (2014). Modeling The Intention to Adopt Cloud Computing Services: A Transaction Cost Theory Perspective. Australian Journal of Information Systems, 18(3), 193-210. https://doi.org/10.3127/ajis.v18i3.1052

Zwattendorfer, B., \& Tauber, A. (2013). The Public Cloud for E-Government. International Journal of Distributed Systems and Technologies, 4(4), 1-14. https://doi.org/10.4018/ijdst.2013100101 